\title{
Identification of Trombiculid Chigger Mites Collected on Rodents from Southern Vietnam and Molecular Detection of Rickettsiaceae Pathogen
}

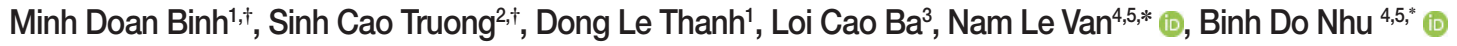 \\ ${ }^{1}$ Ho Chi Minh Institute of Malariology-Parasitology and Entomology, Ho Chi Minh Vietnam; '2Vinh Medical University, Nghe An, Vietnam; \\ ${ }^{3}$ National Institute of Malariology-Parasitology and Entomology, Ha Noi, Vietnam; ' Military Hospital 103, Ha Noi, Vietnam; \\ ${ }^{5}$ Vietnam Military Medical University, Ha Noi, Vietnam
}

\begin{abstract}
Trombiculid "chigger" mites (Acari) are ectoparasites that feed blood on rodents and another animals. A crosssectional survey was conducted in 7 ecosystems of southern Vietnam from 2015 to 2016. Chigger mites were identified with morphological characteristics and assayed by polymerase chain reaction for detection of rickettsiaceae. Overall chigger infestation among rodents was $23.38 \%$. The chigger index among infested rodents was 19.37 and a mean abundance of 4.61. A total of 2,770 chigger mites were identified belonging to 6 species, 3 genera, and 1 family, and pooled into 141 pools (10-20 chiggers per pool). Two pools (1.4\%) of the chiggers were positive for Orientia tsutsugamushi. Ricketsia spp. was not detected in any pools of chiggers. Further studies are needed including a larger number and diverse hosts, and environmental factors to assess scrub typhus.
\end{abstract}

Key words: Oriental tsutsugamushi, Rickettsia sp., chigger mite, ectoparasite

\section{INTRODUCTION}

Trombiculid mites (Acari: Trombiculidae) are ectoparasites that are found in grasses and herbaceous vegetation. The larval mites (chiggers) feed blood on rodents and another animals and birds. More than 3,000 species of chiggers have been identified, but only about 20 species frequently attack humans, and the most relevant species e.g., Eutrombicula alfreddugesi in North and South America, Neotrombicula autumnalis in Europe, and Leptotrombidium spp. in Asia, that are considered to play an important role in transmission of Orientia tsutsugamushi.

The life cycle of Trombiculid mites include 7 stages of active and inactive stages. The larval stage chigger is the only stage of development that parasitizes a wide range of animals, including rats, squirrels, shrews, and birds . Humans are accidentally infected with O. tsutsugamushi through bites of chigger mites in grassy fields, in open and forested areas. The bite sites are on the skin, especially thin and clothing constricts.

- Received 20 April 2020, revised 31 July 2020, accepted 3 August 2020.

*Corresponding authors (drlenam103@gmail.com; nhubinh.do@vmmu.edu.vn)

†These authors contributed equally to this work.

(c) 2020, Korean Society for Parasitology and Tropical Medicine

This is an Open Access article distributed under the terms of the Creative Commons Attribution Non-Commercial License (https://creativecommons.org/licenses/by-nc/4.0) which permits unrestricted non-commercial use, distribution, and reproduction in any

medium, provided the original work is properly cited.
Orientia tsutsugamushi is a gram-negative bacteria and causative agent of scrub typhus, is a vector-borne zoonotic disease with the potential of causing life-threatening febrile infection in humans. Orientia tsutsugamushi, is maintained in the Tromboculid mites through transovarial transmission. Scrub typhus is endemic in South and East Asia regions with more than one billion people at risk with approximately one million new cases reported annually.

There was limited surveillance. Surveys on the species composition of chigger mites were conducted at disperse sites in southern as well as throughout Vietnam. Study on pathogens in chigger mites have not been performed in southern Vietnam.

We performed this cross-sectional study to identify a species composition of chigger mites and presence of rickettsiaceae bacteria, especially Orientia tsutsugamushi in the mites parasitized in rodents collected in southern Vietnam.

\section{MATERIALS AND METHODS}

\author{
Site description \\ Seven ecosystems in southern Vietnam including Bu Gia \\ Map National park (Binh Phuoc province), Can Gio Man-
}


grove Forest (Ho Chi Minh City), Lang Sen Wetland Reserve (Long An province), Lung Ngoc Hoang Nature Reserve (Hau Giang province), Cat Tien National Park (Dong Nai province), U Minh Ha National Park (Ca Mau province), U Minh Thuong National Park (Kien Giang province).

\section{Rodent collection}

Rodent were collected from July to October 2015 (rainy season) and March to April 2016 (dry season). A total of 70 Sherman collapsible live capture traps (H. B. Sherman Traps, Inc., Tallahassee, Florida, USA) at each of the sites were set each night (from 16:00 to 05:00 the following day). Traps were baited with fried fish, potatoes or other local food. Rodents were removed from the traps and placed individually in a white cloth bag labeled with the time of collection, date and an unique collection that identified the survey site and other pertinent information, and then transported to laboratory of Ectoparasitology, Department of Parasitology and Entomology, Ho Chi Minh Institute of Malariology.

Rodents were euthanized at the laboratory of Ectoparasitology Department according to the protocol of Ho Chi Minh Institute of Malariology, Parasitology and Entomology with ketamine $(100 \mathrm{mg} / \mathrm{kg})$ and xylazine $(10 \mathrm{mg} / \mathrm{kg})$ was intraperitoneally injected at dosage of $0.2 \mathrm{ml} / 100$ gm body weight. Rodents were identified to species using morphology and taxonomic keys.

All animals received a good care by well-trained staffs. The study protocols were performed according to the ethical guidelines for care and use of experimental animals approved by the Ethical committee board of Ho Chi Minh Institute of Malariology, Parasitology and Entomology (Permit number 034/2015/ HCMIMPE-IRB).

All personnel were trained on safety measures when conducting investigations, collection, treatment and identification. If participants developed infectious diseases (occupational diseases), they were entitled to benefits and regimes according to current regulations.

\section{Chigger mites collection}

Rodents were carefully examined e.g., the groin, leg, anal area, ear, nose, eyelid, and crest by brushing these areas with fine combs. Then chigger mites were collected into plastic vials containing 70\% ethanol and labeled individually with an unique number assigned to each of survey sites.

\section{Chigger identification}

The chigger mites collected from rodents were identified based on morphologic criteria following taxonomic keys. The chiggers were mounted on glass slides with Hoyer's medium and observed under a binocular microscope at x400 magnification. The key for identification of chigger mite species was based on documents of Van Chau Nguyen. Mites were put on a pool of 10-20 individuals according to their genera and host species. Stored at $4^{\circ} \mathrm{C}$ for pathogen identification.

\section{Rickettsiaceae detection}

The genomic DNA was extracted from the chigger mite pools using the ISOLATE II Genomic DNA Kit (Cat. BIO52066, Bioline, UK) according to the manufacturer's instructions. A final elution volume of $50 \mu \mathrm{l}$ DNA samples were alliquoted into 2 eppendoft tubes and store at $-80^{\circ} \mathrm{C}$ until used.

A multiplex PCR method was performed for the detection and differential diagnosis of Oriental tsutsugamushi and Rickettsia spp. based on 2 primers sets using groEL gene sequences.

In brief, a duplex PCR was run with total reaction volume of $50 \mu \mathrm{l}$, containing $25 \mu \mathrm{l} 2 \mathrm{x}$ MyTaq HS Mix 2x (Bioline, UK); 2.0 $\mu \mathrm{l}$ Multiplex Primer $25 \mathrm{nmol} / \mathrm{l} ; 20 \mu \mathrm{l}$ distilled water and $3 \mu \mathrm{l}$ of DNA template. PCR cycle: $94^{\circ} \mathrm{C}$ for 5 minutes, followed by 45 cycles: $94^{\circ} \mathrm{C}$ for $30 \mathrm{sec}, 56^{\circ} \mathrm{C}$ for 30 seconds, and $72^{\circ} \mathrm{C}$ for 45 seconds and ended at $72^{\circ} \mathrm{C}$ for 7 minutes (Applied Biosystem 2720 Thermocycle; Applied Biosystem, Foster City, California, USA).

All PCR amplicons were electrophorozed in 2\% agarose containing ethidium bromide. Bacteria species were identified based on amplicon size.

\section{Data processing and analysis}

The epidemiological parameters such as mean abundance of chiggers (total number of chiggers collected divided by total number of rodents), chigger infestation rate (percentage of rodents infested with chiggers), and chigger index (total number of chiggers divided by total number of infestedrodents ) were calculated using SPSS software, version 16.0 (SPSS, Chicago, Illinois, USA). Map was drawn using ArcView GIS software, version 3.1 (ESRI).

\section{RESULTS}

A total of 600 rodents belonging to 8 species were captured at 7 sites during 2015 to 2016 (Table 1). Overall, Rattus norvegi- 
Table 1. Number of rodents infected with chigger mites at study sites in southern Vietnam, 2015-2016

\begin{tabular}{|c|c|c|c|c|c|c|c|c|}
\hline \multirow{2}{*}{ Rodent } & \multicolumn{7}{|c|}{ No. rodents infested with chiggers/total trapped rodents } & \multirow{2}{*}{$\begin{array}{c}\text { Subtotal } \\
(\%)\end{array}$} \\
\hline & CG & LS & $\mathrm{LNH}$ & BGM & CT & UMT & UMH & \\
\hline Suncus murinus & $0 / 10$ & $0 / 2$ & $0 / 13$ & $0 / 5$ & $0 / 10$ & $0 / 3$ & $0 / 10$ & $0 / 53(0)$ \\
\hline Ratus norvegicus & $4 / 17$ & $11 / 14$ & $6 / 26$ & $4 / 29$ & $6 / 18$ & $9 / 26$ & $7 / 13$ & $47 / 143(32.87)$ \\
\hline R. argentiventer & $0 / 0$ & $9 / 25$ & $7 / 24$ & $0 / 0$ & $0 / 1$ & $4 / 15$ & $4 / 25$ & $24 / 90(26.67)$ \\
\hline R. fulvescens & $3 / 14$ & $7 / 12$ & $2 / 14$ & $2 / 9$ & $0 / 17$ & $12 / 34$ & $7 / 13$ & $33 / 113(29.20)$ \\
\hline R. edwardsi & $1 / 10$ & $2 / 2$ & $1 / 12$ & $2 / 18$ & $5 / 14$ & $12 ; / 28$ & $4 / 14$ & 27/98 (27.55) \\
\hline R. molliculus & $1 / 9$ & $2 / 22$ & $2 / 9$ & $2 / 8$ & $0 / 11$ & $0 / 11$ & $1 / 8$ & 8/78 (10.26) \\
\hline Mus musculus & $0 / 2$ & $0 / 2$ & $0 / 5$ & $0 / 2$ & 0/0 & $0 / 1$ & $0 / 2$ & 0/14 (0) \\
\hline R. rattus & $0 / 0$ & 0/0 & $0 / 0$ & $2 / 5$ & $1 / 5$ & $0 / 0$ & $1 / 1$ & 4/11 (36.36) \\
\hline Total & $9 / 62$ & $31 / 79$ & $18 / 103$ & $12 / 76$ & $12 / 76$ & $37 / 118$ & $24 / 86$ & $143 / 600(23.38)$ \\
\hline
\end{tabular}

CG, Can Gio Mangrove Forest; LS, Lang Sen Wetland Reserve; LNH, Lung Ngoc Hoang Nature Reserve; CT, Cat Tien National Park; UMH, U Minh Ha National Park; UMT, U Minh Thuong National Park.

Table 2. Species composition and distribution of chigger mites infested on rodents in southern Vietnam, 2015-2016

\begin{tabular}{lcl}
\hline Chigger mite & No. of chiggers & \multicolumn{1}{c}{ Rodent species (host) } \\
\hline Ascoschoengastia (Laurentella) indica & 448 & Rattus fulvescens, R. edwardsi, R. argentiventer, R. norvegicus, R. rattus \\
Gahrliepia (Walchia) chinensis & 678 & R. edwardsi, R. fulvescens, R. molliculus \\
Gahrliepia (Walchia) lupella & 299 & R. argentiventer, R. norvegicus \\
Gahrliepia (Walchia) parapacifica & 111 & R. molliculus \\
Leptotrombidium (Leptotrombidium) deliense & 1,148 & R. edwardsi, R. argentiventer, R. norvegicus, R. molliculus, R. fulvescens, R. rattus \\
Leptotrombidium (Leptotrombidium) striatum & 86 & R. fulvescens, R. edwardsi, R. rattus \\
Total & 2,770 & \\
\hline
\end{tabular}

cus was the most commonly collected rodent (43), followed by R. fulvescens (113), R. edwardsi (98), R. argentiventer (90), $R$. molliculus (78), Suncus murinus (53), Mus musculus (14), R. rattus (11).

A total of 143 rodents belonging to six species infested with chiggers (infestation rate $=23.38 \%$ ). Suncus murinus and Mus musculus were not infested with chigger mites. Rattus rattus had the highest infection rate $36.36 \%$, followed by $R$. norvegicus $32.87 \%$, R. fulvescens $29.20 \%$, R. edwardsi $27.55 \%$, R. argentiventer $26.67 \%$, and R. molliculus $10.26 \%$ (Table 1 ).

\section{Composition and distribution of Chigger mites}

A total of 2,770 chigger mites were collected from 143 rodents with an overall chigger index of 19.37 and a mean abundance of chiggers 4.61 .

Chigger mites belonged to 6 species Ascoschoengastia (Laurentella) indica; Leptotrombidium (Leptotrombidium) deliense, Leptotrombidium (Leptotrombidium) striatum; Gahrliepia (Walchia) chinensis, Gahrliepia (Walchia) lupella, Gahrliepia (Walchia) parapacifica, belonging to 3 genera, and 1 family. L. (L.) deliense, G. (W.) chinensis and As. (L.) indica were the most commonly collected species (Table 2).
The results show that $R$. norvegicus, $R$. fulvescens, $R$. edwardsi and $R$. rattus were the main hosts of 6 chigger mite species, especially Leptotrombidium spp. The remaining rodents were the hosts of some other species. The distribution of chigger mites parasitizing on rodents according to the survey sites were shown in Fig. 1.

The geographical distribution showed that $L$. (L.) deliense was collected from rodents at all surveyed sites, while As. Indica was collected at 6 sites, G. (W.) chinensis and G. (W.) parapacifica at 5 sites. The remaining chigger mite species showed narrow distribution, e.g., G. (W.) lupell was found at 2 survey sites and $L$. (L.) striatum at 3 sites.

\section{Pathogens in chigger mites}

The results showed that $1.4 \%$ pools of chigger mites were positive with Orientia tsutsugamushi (Fig. 2). One sample of Ascoschoengastia (L.) indica was infected O. tsutsugamushi (4.35\%). One pool of $L$. (L.) deliense was infected O. tsutsugamushi (1.72\%). There were not a positive pool for Rickettsia spp. (Table 3).

At 7 survey sites, an O. tsutsugamushi -positive mite pool was found in Bu Gia Map National Park, Binh Phuoc province belonged to As. (L.) indica species (parasitized on R. argentiveter). 


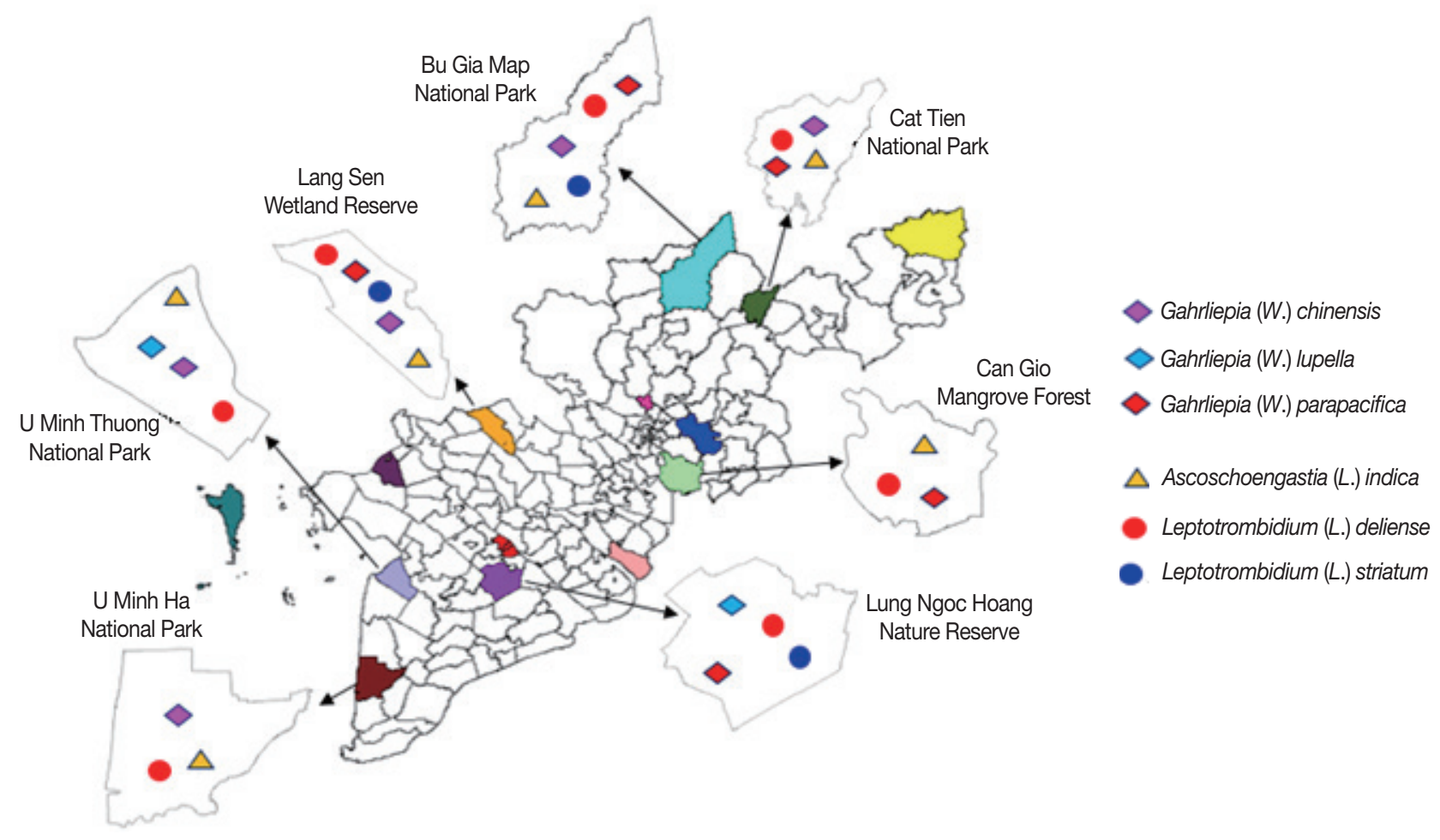

Fig. 1. Geographical distribution of chigger mites at 7 survey sites in southern Vietnam, 2015-2016.

Table 3. Detection rate of rickettsiae in chigger mites by PCR

\begin{tabular}{lccc}
\hline Chigger mite & $\begin{array}{c}\text { No. of pools } \\
\text { (individuals) }\end{array}$ & $\begin{array}{c}\text { No. of pool (\%) } \\
\text { positive with } \\
\text { Rickettsia spp. }\end{array}$ & $\begin{array}{c}\text { No. of pool (\%) } \\
\text { positive with } \\
\text { O. tsutsugamushi }\end{array}$ \\
\hline As. (L.) indica & $23(448)$ & 0 & $1(4.3)$ \\
G. (W.) chinensis & $34(678)$ & 0 & 0 \\
G. (W.) lupella & $15(299)$ & 0 & 0 \\
G. (W.) parapacifica & $6(111)$ & 0 & 0 \\
L. (L.) deliense & $58(1,148)$ & 0 & $1(1.7)$ \\
L. (L.) striatum & $5(86)$ & 0 & 0 \\
Total & $141(2,770)$ & 0 & $2(1.4)$ \\
\hline
\end{tabular}

The other one was $L$. (L.) deliense parasitized on R. norvegicus host collected in U Minh Ha National Park, Ca Mau province (Fig. 3).

\section{DISCUSSION}

Trombiculid mites' habitat is prevalent in an area of overgrown fields, wooded, grassy and herbaceous vegetation. More than 3,000 species of chiggers are known in the world, about 350 species have been described in Southeast Asia .

Chiggers mites (family Trombiculidae) are considered to be

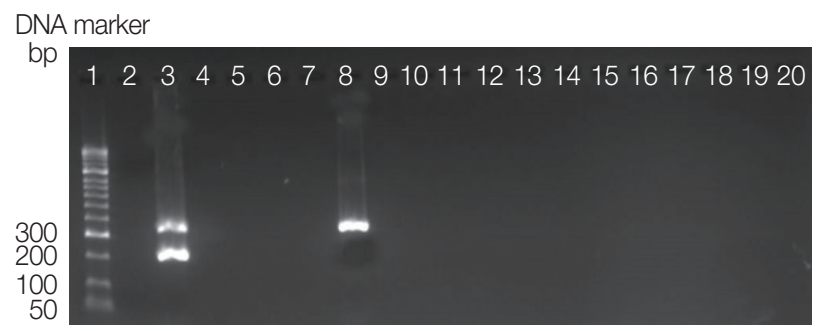

Fig 2. Amplicons of duplex PCR detecting DNA of $O$. tsutsugamushi and Rickettsia spp. Lane 1, DNA size marker; 2, negative; 3, positive of Rickettsia spp. (299 bp) and O. tsutsugamushi (366 bp); Lanes 4-20, chigger mite sample pools.

common ectoparasites of rodents collected from the Mekong Delta, in contrast to gamasid mites, fleas, ticks, and liceare infrequently collected. In our study, 5 per 7 survey sites are in Mekong Delta area, and were forested reserves and parks with abudance of trees, high humidity, lower temperature, light intensity, moist soil and covered with vegetation. It is the ideal environment for the living of trombiculid mites. In the other maner, due to the present human activities, the predator mammals as well as raptorial birds are reduced and the numbers of general species such as squirels and wild birds increased.

The Central South-Southern Region was the region with the 


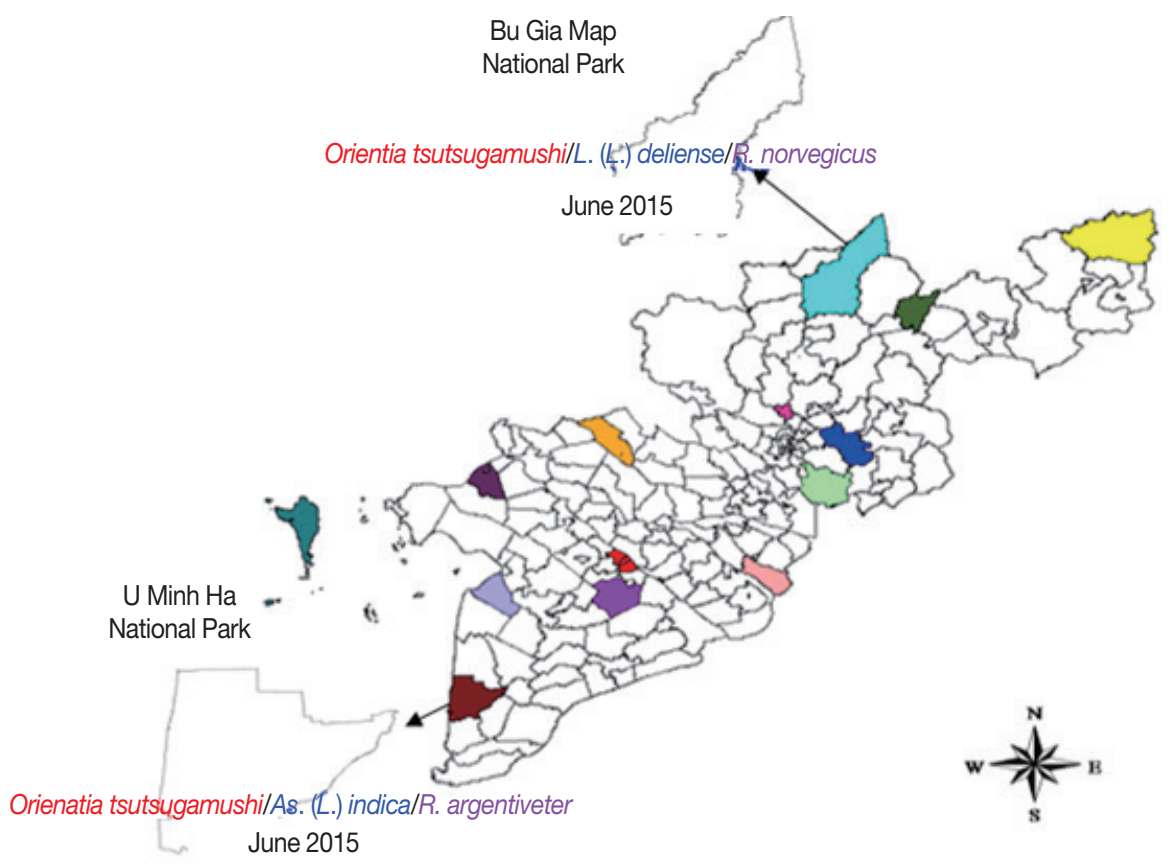

Fig 3. Geographical distribution of rickettsiae in the chigger mites parasitizing on rodents at 7 survey sites in southern Vietnam, $2015-2016$.

highest number of chigger mite genus and species with 62 species (58.5\% of total chigger mite species in Vietnam), 17 genera, and 2 sub-families. Of them, Leptotrombidium and Gahrliepia genera were dominant.

Our result had a lower species composition than other studies that were carried out in different regions of Vietnam such as provinces of Quang Binh and Ha Tinh, 16 species; Con Dao Island, 7 species; Quang Nam and Kon Tum, 6 species. In our study, the chigger mites were only collected from rats, while other studies were retrieved them from rodent host groups (wild birds, rabbits, squirels, raising birds, garbage and animal nests). Of which, 6 species were collected in the rainy season and 5 species were in the dry season. Leptotrombidium (L.) striatum was only collected in the rainy season (July to October) that corresponded to the increasing number of hospitalized scrub typhus patients begun in late August, peaked in October, and then decreased in December.

This hypothesis was further supported by the molecular DNA detection of $O$. tsutsugamushi positive in $1.4 \%$ of the mite pools that collected from rodents in the southern region. Two chigger mite species infected with $O$. tsutsugamushi were L. (L.) deliense and As. (L.) indica. The chiggers of Leptotrombidium spp. are vectors of Orientia tsutsugamushi, the causative agent of scrub typhus.

In Vietnam, among the chigger mites species discovered, there were 5 species, acting as vector of scrub typhus, e.g. L. (L.) deliense, L. (L.) akamushi, L. (L.) scutellare, As (L.) audyi, and As. (L.) indica. In addition, G. (G.) pintanensis and G. (G.) parapacifica have isolated $O$. tsutsugamushi .

The chigger mite infestion rate of $O$. tsutsugamushi in this study was $1.4 \%$ at 7 survey sites and that was lower than $2.7 \%$ at 9 survey sites in Korea, and 17.7\% in Shandong province, China.

This study provided specific data for the species composition, and distribution of chigger mites infested rodents in southern Vietnam and determined the presence of $O$. tsutsugamushi infection. It is very helpful in development of monitoring strategy, prevention and control of scrub typhus transmitted through chigger mites infested in the rodents.

Further studies are needed with a larger number of host sample size, diversity of environmental condition to give the overall geographic distribution and assess the full risk of human exposure to Trombiculid "chigger" mites.

\section{ACKNOWLEDGMENTS}

We thank Dr. Van Chau Nguyen for the confirmation of mite identification and all staffs of the laboratory of Ectoparasitology, Ho Chi Minh Institute of Malariology, Parasitology and Entomology for their assistance during field work. 


\section{CONFLICT OF INTEREST}

The authors declare that there is no conflict of interest regarding the publication of this paper.

\section{REFERENCES}

1. Arlian LG. Chiggers and other disease-causing mites. In VH Resh, R Carde eds, Encyclopedia of Insects, 2nd ed. San Diego, USA. Academic Press. 2009, pp 152-156.

2. Woloski JR, Burman D, Adebona O. Mite and Bed Bug Infections. Primary Care 2018; 45: 409-421.

3. Mullen GR, Durden LA. Medical and Veterinary Entomology. 2nd ed. San Diego, USA. Academic Press. 2009.

4. Traub R, Wisseman CL Jr. The ecology of chigger-borne rickettsiosis (scrub typhus). J J Med Entomol 1974; 11: 237-303.

5. McClain D, Dana AN, Goldenberg G. Mite infestations. Dermatol Ther 2009; 22: 327-346.

6. Pham XD, Suzuki H, Takaoka H. Distribution of unengorged larvae of Leptotrombidium pallidum and other species in and around the rodent nest holes. Southeast Asian J Trop Med Public Health 2001;32: 553-557.

7. Masakhwe C, Linsuwanon P, Kimita G, Mutai B, Leepitakrat S, Yalwala S, Abuom D, Auysawasi N, Gilbreath T, Wanja E, Waitumbi J. Identification and characterization of Orientia chuto in trombiculid chigger mites collected from wild rodents in Kenya. J Clin Microbiol 2018; 56: e01124-18.

8. Santibáñez P, Palomar AM, Portillo A, Santibáñez S, Oteo JA. The role of chiggers as human pathogens. In Samie A ed, An Overview of Tropical Diseases. 2nd ed. London, UK. IntechOpen; 2015, pp 173-202.

9. Hadi TR, Carney WP. Two new trombiculid mites from mammals of South Vietnam, with locality records for six additional species (Acarina: Trombiculidae). J Med Entomol 1977;14: 455-460.

10. Dong LT, Minh DB. Determine the presence of pathogens on ticks in the Mekong Delta Region. In Toi VV, Le TQ, Ngo HT, Nguyen TH eds, International Conference on the Development of Biomedical Engineering in Vietnam. Singapore, Singapore. Springer. 2018, pp 707-713.

11. Can DN, Endo H, Son NT, Oshida T, Canh LX, Phuong DH, Lunde DP, Kawada SI, Hayashida A, Sasaki M. Checklist of wild mammals species of Vietnam. Hanoi, Vietnam. Institue of Ecology and Biological Resources. 2008, pp 400 (in Vietnamese).

12. Balakirev AE, Abramov AV, Rozhnov VV. Taxonomic revision of Niviventer (Rodentia, Muridae) from Vietnam: a morphological and molecular approach. Russian J Theriol 2011;10: 1-26.

13. Huy HD. Checklist of Mammals in Vietnam. Hanoi, Vietnam. Hanoi Publishing House. 1994; pp 168.

14. Van Chau N. The distribution and species composition of medical arthropod in the Quang Binh and Ha Tinh along Ho Chi Minh road. J Malaria Parasite DisControl 2003: 54-63 (in Vietnamese).

15. Van Chau N. Chigger Mites (Acariformes: Trombiculidae) Classification in Vietnam. Beijing, China. Medical Publishing House. 1997, pp 48.

16. Park HS, Lee JH, Jeong EJ, Kim JE, Hong SJ, Park TK, Kim TY, Jang WJ, Park KH, Kim BJ, Kook YH, Lee SH. Rapid and simple identification of Orientia tsutsugamushi from other group rickettsiae by duplex PCR assay using groEL gene. Microbiol Immunol 2005; 49: 545-549.

17. Nadchatram M, Dohany AL. A Pictorial Key to the Subfamilies, Genera and Subgenera of Southeast Asian Chiggers (Acari, Prostigmata, Trombiculidae). Kuala Lumpur, Malaysia. Institute Penyelidikan Perubatan. 1974.

18. Goff ML, Loomis RB, Welbourn WC, Wrenn WJ. A glossary of chigger terminology (Acari: Trombiculidae). J Med Entomol 1982; 19: $221-238$.

19. Loan HK, Cuong NV, Takhampunya R, Klangthong K, Osikowicz L, Kiet BT, Campbell J, Bryant J, Promstaporn S, Kosoy M, Hoang NV, Morand S, Chaval Y, Hien VB, Carrique-Mas J. Bartonella species and trombiculid mites of rats from the Mekong Delta of Vietnam. Vector Borne Zoonotic Dis 2015; 15: 40-47.

20. Van Nguyen C, Do HT, Nguyen KT, Phung BX, Nguyen LTB, Nguyen BTH, Le TA, Le KT. Results of medical arthropod surveys in the natural conserve zone-Can Gio mangrove forests, Ho Chi Minh city. J Malaria Parasite Dis Control 2004: 61-68.

21. Chinh Vu Duc DTT, Nguyen VC. Results of the survey on medical arthropod in con dao island. J Malaria Parasite Dis Control 2006: 66-74.

22. Van Chau N. Species composition of medical arthropod in the provinces of Quang Nam and Kon Tum along Ho Chi Minh road. J Malaria Parasite Dis Control 2004: 73-81.

23. Huang XD, Cheng P, Zhao YQ, Li WJ, Zhao JX, Liu HM, Kou JX, Gong MQ. Chigger mite (Acari: Trombiculidae) survey of rodents in Shandong Province, Northern China. Korean J Parasitol 2017; 55: 555-559.

24. Lerdthusnee K, Khlaimanee N, Monkanna T, Sangjun N, Mungviriya S, Linthicum KJ, Frances SP, Kollars TM Jr, Coleman RE. Efficiency of Leptotrombidium chiggers (Acari: Trombiculidae) at transmitting Orientia tsutsugamushi to laboratory mice. J Med Entomol 2002; 39: 521-525.

25. Lee HI, Shim SK, Song BG, Choi EN, Hwang KJ, Park MY, Park C, Shin EH. Detection of Orientia tsutsugamushi, the causative agent of scrub typhus, in a novel mite species, Eushoengastia koreaensis, in Korea. Vector Borne Zoonotic Dis 2011; 11: 209-214.

26. Zhang M, Zhao ZT, Yang HL, Zhang AH, Xu XQ, Meng XP, Zhang HY, Wang XJ, Li Z, Ding SJ, Yang L, Zhang LY. Molecular epidemiology of Orientia tsutsugamushi in chiggers and ticks from domestic rodents in Shandong, northern China. Parasit Vectors 2013; 6: 312. 